\title{
Peculiarities of pyroxenite paragenesis garnets distribution in Yakutian kimberlites and some aspects of the Siberian craton lithospheric mantle evolution.
}

\author{
Pokhilenko, N.P. ${ }^{1}$, Sobolev, N.V. ${ }^{1}$, Kuligin, S.S. ${ }^{1}$, and Shimizu, ${ }^{2}$.
}

1. Institute of Mineralogy and Petrography, Novosibirsk, 630090, Russia

2. Department of Geology and Geophysics, Woods Hole Oceanographic Institution, Woods Hole, MA 02543, USA.

Three intense cycles of kimberlite magmatism activity are known on the Siberian Platform: Upper Devonian-Lower Carboniferous (370-345 Ma), Triassic (240-220 Ma), and Upper Jurassic (150-135 Ma) (Davis et al., 1980; Brachfogel, 1995). Another paramount event of the Phanerozoic stage of the Siberian Platform evolution was a huge but relatively short-term cycle of trap magmatism at the Permian-Triassic border, with its maximum intensity expressed 235-230 Ma ago (Zolotukhin, Almukhamedov, 1988; Baksi, 1990).

Thus, two cycles of kimberlite magmatism, Upper Devonian-Lower Carboniferous and Upper Jurassic, and the peak of intensity of the Jurassic trap magmatism were separated by considerable gaps of $110 \mathrm{Ma}$ and $70 \mathrm{Ma}$, respectively. The kimberlite fields formed during the Upper DevonianLower Carboniferous are known both for central and northeastern regions of the Yakutian Kimberlite Province, while the Upper Jurassic kimberlites have been established only in the north and northeast.

Comparative analysis of the distribution of compositions of representative samples of pyropes ( $>100$ grains from each body) from the concentrates of several tens of heterochronous pipes in the central and northern fields of the province as well as pyropes from the Lower Carboniferous conglomerates developed within the Kyutyungda graben on the northeastern margin of the Siberian Platform (Sobolev et al., 1981) showed that:

1. Pyropes from the Middle Paleozoic kimberlites from the central and northern regions are very close in $\mathrm{CaO}$ and $\mathrm{Cr}_{2} \mathrm{O}_{3}$ variations for compositions corresponding to lherzolite and harzburgitedunite parageneses; a distinguishing feature of the Middle Paleozoic kimberlites from the northern regions is the nearly complete absence of $\mathrm{Ca}$-rich $\mathrm{Cr}$-pyropes of wehrlite paragenesis which are rather common in the kimberlites from the central regions (Sobolev et al., 1973).

2. A typical feature of the garnet complex from the Upper Jurassic kimberlites is a many-fold increased share of pyropes of pyroxenite parageneses in them as compared with the garnets from the Paleozoic kimberlites; this is expressed in significantly increased of $\mathrm{FeO}$ average and decreased $\mathrm{Cr}_{2} \mathrm{O}_{3}$ contents (see Table 1).

3. In the kimberlites of Upper Jurassic age the role of pyropes with a high ( $>7 \mathrm{wt} . \%)$ admixture of $\mathrm{Cr}_{2} \mathrm{O}_{3}$ drastically drops: for example, the amount of these pyropes for 32 pipes of Middle Paleozoic age from the Daldyn and Alakit fields averages $15.2 \%$, and for 26 pipes of Upper Jurassic age from the Lower Olenek region it averages $2.1 \%$ (see Table 1).

Detailed study of the complex of mantle rock xenoliths from the heterochronous kimberlites of the Siberian Platform has shown that the thickness of the lithosphere of the central regions in the Paleozoic time was no less than $250 \mathrm{~km}$ at heat flows in the range from 36 to $39 \mathrm{mWm}^{-2}$ (Pokhilenko et al., 1991; 1993; Griffin et al., 1995; Boyd et al., 1997). The complex of mantle-derived xenogenous material from the Upper Jurassic kimberlites in the northeastern part of the Siberian Platform characterizes the considerably less thickness of the lithosphere (no more than $150 \mathrm{~km}$ ) with heat flows being no less than $40 \mathrm{mWm}^{-2}$ at that time. On the other hand, Ni-Cr thermobarometry of the pyropes from the Middle Paleozoic kimberlites on the same territory gives the lithosphere 
thicknesses and heat flows comparable with those for the Middle Paleozoic kimberlites from the central parts of the platform (see Fig.1).

A considerably increased role of pyroxenites in the lithosphere mantle of the Siberian Platform, joint with a significant increase in the total thickness of the lithosphere, may be due to the processes of erosion (thinning) of the lithosphere mantle as a result of the active interaction of the lithosphere roots with melts of asthenosphere origin during an intense cycle of trap magmatism, covering a territory of about $1.5 \mathrm{mln} \mathrm{km}^{2}$ (Pokhilenko, Sobolev, 1995).

The of transformation of the harzburgite-dunites from the lithosphere roots into lherzolites and wehrlites as a result of the interaction with mantle-derived melts is documented at different stages of its evolution by rare findings of these rocks in the xenolith complex (Shimizu et al., 1994; 1997). We have found and explored a unique xenolith of peridotite with unambiguous signs of its primary paragenesis of harzburgite-dunite type and its successive transformation into wehrlite and then into lherzolite; the amount of clinopyroxene completely missing from the primary rock reached 30-35 vol. \% in the end product. The presence of the rocks of this composition in the mantle corroborates our scheme suggesting significant transformation of the lower levels of the lithosphere mantle when trap magmatism intensely developed within the Siberian Platform.

Table1. The compositional peculiarities of the garnets of ultrabasic paragenesis from the Yakutian kimberlites (Pokhilenko et al., 1988).

\begin{tabular}{|c|c|c|c|c|c|c|}
\hline $\begin{array}{c}\text { Kimberlite } \\
\text { regions }\end{array}$ & $\frac{\mathrm{N}}{\mathrm{n}}$ & $\begin{array}{c}\mathrm{FeO} \\
\mathrm{x} / \mathrm{S}\end{array}$ & $\begin{array}{c}\mathrm{Cr}_{2} \mathrm{O}_{3} \\
\mathrm{x} / \mathrm{S}\end{array}$ & $\mathrm{n}_{1}, \%$ & $\mathrm{n}_{2}, \%$ & $\mathrm{n}_{3}, \%$ \\
\hline Daldyn-Alakit & $\underline{32}$ & $\underline{8.06}$ & $\frac{4.20}{2.34}$ & 35.8 & 15.2 & 3.2 \\
\hline Lower Olenek & $\underline{26}$ & $\underline{9.44}$ & $\frac{2.75}{1.62}$ & 4.8 & 2.1 & 0.0 \\
\hline
\end{tabular}

$\mathrm{N}$ - amount of researched pipes; $\mathrm{n}$ - amount of analyzed garnet grains.

$\mathrm{n}_{1}$. amount of pyropes with $\mathrm{Cr}_{2} \mathrm{O}_{3}>5 \mathrm{wt} . \%$

$\mathrm{n}_{2}$ - amount of pyropes with $\mathrm{Cr}_{2} \mathrm{O}_{3}>7 \mathrm{wt} . \%$

$\mathrm{n}_{3}$ - amount of pyropes with $\mathrm{Cr}_{2} \mathrm{O}_{3}>10 \mathrm{wt} . \%$

Fig.1. The estimations of lithosphere thickness and geotherm character for the North-Eastern marginal zone of the Siberian Platform at Middle Paleozoic and Upper Jurassic time.

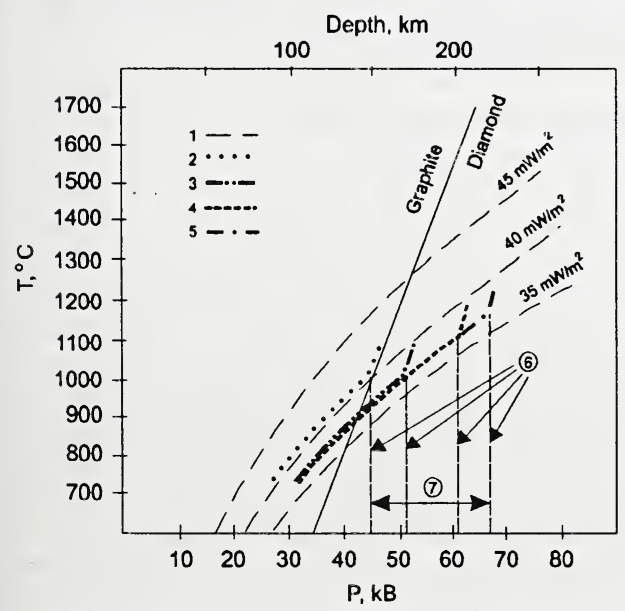

1.The geotherms calculated for the heat flows of various intensity.

2.The geotherm for Lower Olenek region (Upper Jurassic time).

3.The geotherm for the lithosphere under Ivushka pipe (Middle

Paleozoic time).

4.The geotherm of the South-Westem board of Kyutyungda graben

(Middle Paleozoic time).

5.The geotherm for the North-Eastern board of Kyutyungda graben (Middle Paleozoic time).

6.The estimations of maximal pressures and depths of the root parts of lithosphere for the areas 2-5 at various time.

7.The maximal interval of lithospherc crosion of the region during the period between Lower Carboniferous and Upper Yurassic time. 


\section{References}

Baksi, A.K., 1990, Timing and duration of Mesozoic-Tertiary floodbasalt volcanism: Eos 71, p. $1835-1836$.

Boyd, F.R, Pokhilenko, N.P., Pearson, D.G., Mertzman, S.A., Sobolev, N.V., Finger, L.W., 1997, Composition of the Siberian cratonic mantle: evidence from Udachnaya peridotite xenoliths: Contrib. Mineral. Petrol., p. 228-246.

Brakhfogel, F.F., 1995, The Age division of the kimberlitic and related magmatites in the North-East of the Siberian Platform (methods and results): Extended Abstracts $6 \mathrm{IKC}$, Novosibirsk, p.60-62.

Davis, G.L., Sobolev, N.V., Kharkiv, A.D., 1980, New data on the age of Yakutian kimberlites obtained by U-Pb method by zircons: Dokl. Akad. Nauk SSSR, , v. 254, p. 175-179 (in Russian).

Griffin, W.L., Kaminsky, F., O’Reilly, S.V., Ryan, C.G., Sobolev, N.V., 1995, Mapping the Siberian lithosphere with garnets and spinels: Extended Abstracts 6 IKC, Novosibirsk, p. 194-195.

Pokhilenko, N.P., Pearson, D.G., Boyd, F.R., Sobolev, N.V., 1991, Megacrystalline dunites and peridotites: hosts for Siberian diamonds: Annual Report Dir. Geophys. Lab. Carn. Inst., Washington, p. 11-18.

Pokhilenko, N.P., Sobolev, N.V., 1995, Mineralogical mapping of the North-East section of the Yakutian kimberlite province and its main results: Extended Abstracts $6 \mathrm{IKC}$, Novosibirsk, p.446-448.

Pokhilenko, N.P., Sobolev, N.V., Boyd, F.R, Pearson, D.G., and Shimizu, N., 1993, Megacrystalline pyrope peridotites in the lithosphere of the Siberian Platform: mineralogy, geochemical peculiarities and the problem of their origin: Geologiya i Geofizika, N 1, v. 34, p. 56-68.

Pokhilenko, N.P., Sobolev, N.V., Safronov, A.F. et al., 1988, Magnesian garnets from kimberlites of the Northen part Siberian platform: Composition and processes of deep-seated zones of continental lithoshere: Extended Abst. Int. Symp., Novosibirsk, p. 75-77.

Shimizu, N., Boyd, F.R., Sobolev, N.V. Pokhilenko, N.P., 1994, Chemical zoning of garnets in peridotites and diamonds: Miner. Mag., v. 58A, p. 831-832.

Shimizu, N., Pokhilenko, N.P., Boyd, F.R., Pearson, D.G., 1997, Geochemical characteristics of mantle xenoliths from Udachnaya kimberlite pipe: Russian Geology and Geophysics, v. 38, N 1, p. 194-205.

Sobolev, N.V., Belik, Yu.P., Pokhilenko, N.P., Krivonos, V.F., Polyakov, V.N., 1981,. Cr-bearing pyropes in carboniferous deposits of Kyutyungda depression: Geologiya i Geofizika, N 2, p. 153-157.

Sobolev, N.V., Lavrent'ev, Yu.G., Pokhilenko, N.P., Usova, L.V., 1973, Chrome-rich garnets from the kimberlites of Yakutia and their parageneses: Contrib. Mineral. Petrol., v. 40, p. 39-52.

Zolotukhin, V.V. and Al'mukhamedov, A.I., 1988, Traps of the Siberian Platform. J.D.Macdougall (ed.), Continental Flood Basalts: by Kluver Academic Publisher, Amsterdam, p.273-310. 